PART 1

The Unbounded Nature of Domestic Space 
Remi Chiu - 9789004375871

Downloaded from Brill.come4/26/2023 07:44:24AM via free access 


\title{
Singing on the Street and in the Home in Times of Pestilence: Lessons from the $1576-78$ Plague of Milan
}

\author{
Remi Chiu
}

When plague returned to Europe in 1348 after an absence of nearly six hundred years, few could have guessed that the disease would continue to haunt the continent for the next four centuries. ${ }^{1}$ A number of factors made the disease horrifying: it recurred in unpredictable cycles; it produced grotesque symptoms such as buboes and necrosis of the extremities; it had a high mortality rate; and it spread easily and killed quickly (Boccaccio writes that victims of plague 'having breakfasted in the morning with their kinsfolk, acquaintances and friends, supped that same evening with their ancestors in the next world!'). ${ }^{2}$ Moreover, unlike other ailments such as leprosy, plague did not mark individuals, but rather besieged entire populations. This last attribute of plague had important moral implications. If disease, as it was thought, was ultimately divine punishment for sin, then it followed that plague impugned not only the virtue of an individual, but the collective morality of a community. Corrective action, therefore, had to be carried out communally.

This essay examines the ritual of the plague procession as a response to the problem of collective sin, using as the focal point a series of well-documented processions held by Carlo Borromeo, the Archbishop of Milan, during the city's outbreak of $1576-78$. It will first explore the ways in which music, as a central component of the procession, interacted with other elements of the ritual to facilitate corporate worship while strengthening the civic bonds of the processional community. However, large congregations of people in processions exacerbated the very real threat of contagion and contravened medical and civic rules for isolation. The second half of this essay will investigate how Borromeo coped with this struggle between piety and public safety by relocating the procession off the public streets and into private homes when parishes were placed under quarantine. In Borromeo's ad hoc program of devotion, most ritual elements were pared away, leaving music as the primary tool by which

1 Research for this essay was supported by the Wellcome Trust (106651/Z/14/Z).

2 Boccaccio Giovanni, The Decameron, trans. G.H. McWilliam (London: 2003) 13.

(C) REMI CHIU, 2019 | DOI:10.1163/9789004375871_003

This is an open access chapter distributed under the terms of the prevailing CC-BY-NC-ND License at the time of publication. 
the Milanese were able to maintain their corporate devotional activities and to erase the boundaries between public and domestic worship.

According to surviving chronicles, plague entered Milan in either late July or early August of 1576 and reigned until the city was declared 'liberated' on 20 January 1578, meaningfully coinciding with feast day of St. Sebastian, one of the premier protectors against pestilence. Over those eighteen months, the city lost over 17,000 individuals, roughly $15 \%$ of her citizens. ${ }^{3}$ No one knew for certain how plague could have breached the city's walls, given that Milan was already on alert. Trent, the ground zero for the epidemic, was struck just a year earlier. From there, the disease progressed first to Venice and Mantua in the early part of 1576 before finally reaching Milan. Within a month of the outbreak, most of Milan's nobility had fled. Even more distressing for the Milanese, 'the evils produced by this state of things were increased' when the Governor, the Marquis of Ayamonte, likewise abandoned his city and took refuge in nearby Vigevano. ${ }^{4}$ Conditions deteriorated throughout the autumn on both the medical and the civic fronts. Trade and commerce faltered, and it became difficult for the government to provision the city with goods from uninfected regions. The city's plague hospital quickly filled to capacity, and more temporary straw huts for the sick were needed than could be built. ${ }^{5}$ Increasingly draconian measures were enacted - such as the purging of infected homes, closure of non-essential shops, and a general quarantine - all of which further exacerbated the city's financial troubles. ${ }^{6}$

3 Figure based on Stefano D'Amico's estimate of the city's population in 1574 in "Crisis and Transformation: Economic Organization and Social Structures in Milan, 1570-1610", Social History 25, 1 (2000) 4. Robert Kendrick puts the figure slightly lower, at 80,000 to 100,000 citizen inside Milan's walls; The Sounds of Milan, 1585-1650 (Oxford: 2002) $411 n 25$.

4 Bisciola Paolo, Relatione verissima del progresso della peste di Milano. Qual principiò nel mese d'Agosto 1576, e segui sino al mese di Maggio 1577 (Bologna, Carlo Malisardi and Sebastiano Balestra: 1630) 2r; Giussano Giovanni Pietro, The Life of St. Charles Borromeo, Cardinal Archbishop of Milan: From the Italian of John Peter Giussano; With Preface by Henry Edward Cardinal Manning [Vita Di S. Carlo Borromeo (Rome, 1610)] (London - New York: 1884) 369, 384-385.

5 Besta Giacomo Filippo, Vera narratione del successo della peste, che afflisse l'inclita città di Milano l'anno 1576 et di tutte le provisioni fatte a salute di essa città (Milan, Paolo Gottardo, \& Pacifico Pontii, fratelli: 1578) 22r-v.

6 Besta, Vera narratione $25 \mathrm{v}-29 \mathrm{r}$. 
Carlo Borromeo took over where the Milanese officials left off, marshalling the clergy to maintain the city's temporal and spiritual welfare. He organised the cleaning of homes and streets, and ordered the culling of dogs and cats; he conducted charitable relief work, selling his possessions, spending his own wealth, and borrowing money when his personal funds ran low; and, dismissing concerns over infection, he made visitations across the diocese and even personally ministered to the sick. ${ }^{7}$

\section{2 The Pestilential Procession}

One of Borromeo's most frequently noted pastoral acts during the crisis - one that would later become an indelible part of his cultic hagiography - was the organisation of three general processions in October $1576 .{ }^{8}$ Each of the processions began at the city's cathedral, with the first terminating at the Basilica of Sant'Ambrogio, the second at San Lorenzo, and the third at Santa Maria presso San Celso. With the added incentive of a plenary indulgence, the processions attracted an enormous number of participants, including any noblemen and civic officials who were left, ordinary citizens, and at least a thousand flagellants in tow. Borromeo wore a noose around his neck and walked barefoot to evoke the image of a condemned criminal. During the first procession, he reportedly cut his foot on an iron railing, but instead of tending to the wound, he walked on, letting his blood flow freely for all to see. Witnesses to the wound were all moved to compassion and cried out, 'Miserere! Miserere!' The third and final procession was to be the most solemn. Borromeo bid the parochial clergy to bring out their most prized relics in order to both move the masses to devotion and appeal to the saints. He himself carried the prized Milanese relic from the Cathedral, the Holy Nail, attached to a cross. At the close of this procession, Borromeo returned to the Cathedral and began a forty-hour devotion.

The ritual model that Borromeo invoked to rally support for his procession was established nearly a millennium earlier by Gregory I during a Roman

7 Bisciola, Relatione verissima 5 v-6r. See also de Boer W., The Conquest of the Soul: Confession, Discipline, and Public Order in Counter-Reformation Milan (Leiden - Boston: 2001) 79-80.

8 Jones P.M., "San Carlo Borromeo and Plague Imagery in Milan and Rome", in Bailey G.A. et alia (eds.), Hope and Healing: Painting in Italy in a Time of Plague, 1500-1800 (Worcester: 2005) 65-96; Crawfurd R., Plague and Pestilence in Literature and Art (Oxford: 1914) 171-175; Getz C., "Canonising San Carlo: Sermonising, the Sounding Word, and Image Construction in the Music for Carlo Borromeo", Early Music History 34 (2015) 133-189. 
outbreak in 590. ${ }^{9}$ As recounted in the Legenda aurea, the Romans, having lived a continent life throughout Lent, threw off all restraints after Easter and lived sinfully, for which they were heartily punished with buboes on their bodies..$^{10}$ Amid the scourge, Pope Gregory summoned the entire Roman populace to a sevenfold or septiform litany, so-called because seven classes of people - clergy, monks and religious men, religious women, children, laymen, widows and unmarried women, and married women, each group accompanied by priests from the seven ecclesiastical districts of the city - were to gather separately at seven different churches throughout Rome and then process together toward the Basilica S. Maria Maggiore. The penitents took to the streets, chanting litanies and singing 'Miserere'. Death was among the ranks, however, as eighty penitents fell dead in the space of an hour. As he headed the trains of suffering Romans, Gregory carried an image of Mary - the Salus populi Romani - purportedly made by St. Luke himself, which miraculously cleansed the surrounding air of infection as it moved through the city. As Gregory approached the Aelian Bridge, the Archangel Michael appeared atop the castle of Crescentius (now the Castel Sant'Angelo) and sheathed his bloody sword as a sign that God had been placated by the pious outpouring. And indeed, the Legenda aurea tells us, the plague promptly came to an end.

Processions such as Gregory's and Borromeo's were held across Europe in times of plague. They aimed, in the first instance, to rectify the relationship between the participants and their punitive God - in the case of Milan, a relationship that Borromeo felt had long been strained by the moral lassitude of the citizens in the years leading up to the outbreak. ${ }^{11}$ Subsumed under the processions' similarities in purpose and ritual framework, however, were local variations in practices that worked together toward a secondary goal of securing civic identification and solidarity. At the most basic, the very route of the procession itself was necessarily unique for every city. The different itineraries also meant that the penitents had the opportunity to make station and pray at different shrines and churches along the way, and to honour patrons and intercessors who were particularly important to the community. The relics displayed during a procession had to be chosen with special care for their proven efficacy and special relationship to the participants; the Romans used

9 Giussano, Life of St. Charles Borromeo 390-391. Gregory's plague procession was the first recorded instance of such ritual of affliction within the Christian context.

10 Jacobus, The Golden Legend: Readings on the Saints, trans. W.G. Ryan, 2 vols. (Princeton: 1993) 1:171-174; see also Mollaret H.H. - Brossollet J., "La procession de saint Grégoire et la peste à Rome en l'an 590", Médecine de France 199, 13 (1969) 13-22.

11 Lezowski M., "Portraits de Milan par Charles Borromée (1564-1584): La dynamique rigoriste de l'écriture", Seizième siècle 9 (2013) 135-140. 
the Salus populi Romani in 590, the Venetians favoured a Byzantine icon of the Madonna, and Borromeo brought out the Holy Nail. When another major outbreak hit Milan in 1630, it was St. Carlo Borromeo's exhumed body that was carried in procession, a choice of relic meant to recall and honour the cardinal's successful stewardship of the city in the earlier crisis. The holy totems chosen for processions, therefore, expressed a particular civic identity that drew on the shared spiritual history of a given people.

The physical organisation of the participants, too, reflected the demographic make-up and political ideologies of a society. Gregory's septiform procession distinguished the different kinds of clergy and the laity by gender, marital status, and age. Venetian processions put into practice the republic ideology of La Serenissima, based on clear and stable hierarchies: the Doge walked in the center of the procession; before him, civil servants were ranked in an ascending order of prestige, and behind him, noble magistrates followed in descending order of status. ${ }^{12}$ The Doge was like a living relic whose power and magnificence emanated outward. In Borromeo's plague processions, chroniclers noted that the archbishop came first, followed by the governor and the members of the Senate, with the clergy and the general population following them in turn. ${ }^{13}$ The laity was separated into parishes and marched under separate parish banners. This arrangement, Borromeo reasoned, would also diminish the risk of contagion across neighbourhoods. ${ }^{14}$

The liturgical-musical elements of the plague procession worked in tandem with these other ritual elements in propitiating the divinities and unifying the community. On the evidence of sacerdotal manuals, the core ritual framework of crisis processions, such as processions for rain or the cessation of plague, followed the form of the Major Litanies. In general, Psalms (usually one of the Penitential Psalms, 6, 31, 37, 50, 101, 129, and 142) $)^{15}$ and antiphons were performed at the point of departure. During the actual ambulation, the litany, usually the Litany of the Saints, was sung along with more Psalms and repeated

\footnotetext{
12 Muir E., Civic Ritual in Renaissance Venice (Princeton: 1981) 203.

13 Besta, Vera narratione $15 \mathrm{v}-16 \mathrm{r}$. For the hierarchical organization and separation of participants (including their distinguishing manners of dress) in Milanese general processions during the Counter-Reformation, see Dallaj A., "Le Processioni a Milano Nella Controriforma", Studi Storici 23, 1 (1982) 172-183.

14 Giussano, Life of St. Charles Borromeo 391.

15 These are Vulgate numberings.
} 
as necessary. At the conclusion of the ritual, prayers at the terminus renewed the foregoing petitions, and a Missa contra pestem was to be celebrated.

Special pamphlets containing the prayers of plague processions were sometimes issued, and they can help us flesh out the liturgical programme of a given procession. For the ritual in Milan, Borromeo published the Antiphonae, psalmi, preces, et orationes ad usum supplicationum tempore pestis, a palm-sized booklet ( 21 folios, $13 \mathrm{~cm}$ by $7.5 \mathrm{~cm}$ ) that could easily have been carried in procession. ${ }^{16}$ The book opens with a selection of seven antiphons and the seven Penitential Psalms, to be performed 'pro arbitratu'. Three additional Psalms (94, 87 and 9o) and two biblical readings (Jonah 2 and Isaiah 38) follow, again to be performed as the participants see fit. The Litany of the Saints comes next, followed by a reprint of Psalm $5^{0}$ and then a set of five short prayers, the first of which is merely a rubric instructing the supplicants to perform a prayer to the saint in whose church they find themselves ('de Sancto, in cuius Ecclesia supplicationes fiunt'). The rest are prayers for mercy and protection. Indicating the intended Milanese use of pamphlet, Oratio II and $v$ respectively invoke Saint Ambrose as 'patron[us] nost[er]' and 'Pontif[ex] nost[er]'. At the end of the pamphlet, seven additional propitiatory prayers are provided.

The dominant and 'iconic' sound of the plague procession was undoubtedly the litany, a word that stands in as a synecdoche for the term 'procession' itself. In the Litany of the Saints, the bulk of the prayer is a roll-call of divinities where each invocation sung by cantors is punctuated by the response of the general processional body: 'ora/orate pro nobis' [Fig. 1.1]. On account of its predominantly call-and-response structure, the litany is a useful musical tool for uniting the participants. The complete meaning of the litany prayer emerges in performance only through the coordinated participation of a penitential community - the call from a leader has to be met by a response, so every member of procession becomes indispensable to the success of the ritual. The very melodic profile of the litany encourages that participation. The invocation forms an upward melodic arch that stops at (what we would call today) the 'leading-tone', a point of melodic instability that necessitates a musical completion. The response begins where the invocation leaves off and returns to the initial note, the 'tonic', through a downward arc, preparing the votaries for another iteration of the call. Moreover, with its narrow range and simple tunefulness, the litany is easily accessible. An account by Paolo Bisciola, a chronicler of the Borromean plague, reveals how 'democratic' this prayer can be: the Cardinal 'having by chance seen a poor woman praying in the street to

16 Borromeo Carlo, Antiphonae, psalmi, preces, et orationes, ad usum supplicationum tempore pestis (Milan, Pacificum Pontium: 1576). 


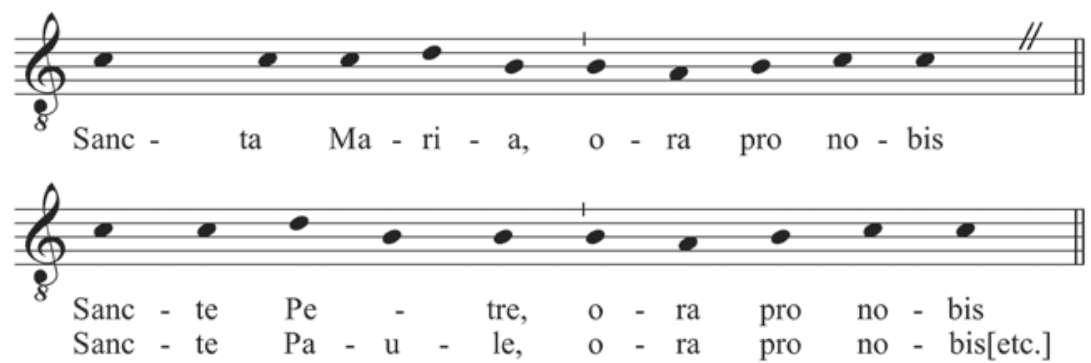

FIGURE 1.1 Excerpt from Litany of the Saints (Liber usualis)

an image which she had attached to a wall, was so delighted by this devotion that he sent a number of his followers out into the streets to teach the people to sing the litanies.' ${ }^{17}$ Gender, poverty, and lack of education were not barriers to the learning of this simple and repetitive Latin prayer, allowing all the penitents to participate meaningfully in the central liturgy of the procession. And as they sing the litany on the march, the participants send out an audible pulse through the marching group and provide an ambulatory rhythm that unites them. Weaving back and forth, the litany acts as a sonic thread that sutures together the constituent parts of the processional body.

In addition to facilitating the kinetics of the public procession, the litany draws the participants into a shared devotional history and culture through the list of names invoked. Like the itinerary of a procession or the choice of relics carried therein, the roll-call of names was highly customisable - and customised - to reflect the special relationships between votaries and divine patrons. A cursory comparison between the Litany in Borromeo's processional pamphlet and the Litany in a similar pamphlet issued by the Pope in the same year (Litaniae, et preces [...] pro avertenda a populo Christiano pestilentia) shows that the roll-call in the former, invoking around ninety specific names, is nearly twice the length of the latter. ${ }^{18}$ Many of these extra names in the Milanese litany (some fairly obscure), such as Nazarius, Celsus, Sisinnius, Martyrius, Calimerus and Miroclus, bear local significance as saints who were either associated with the city during their lifetimes or whose relics were kept by the Milanese. It may be that, because the Pope's pamphlet described Roman usage and was intended to be serviceable for a wider number of liturgical centers, the list was only a template that invited local accretions and ex tempore

\footnotetext{
17 Bisciola, Relatione verissima $3 \mathrm{v}$.

18 Catholic Church, Litaniae et preces iussu S.D.N. Gregorij Papae XIII in omnibus ecclesijs dicendae ad implorandum diuinum auxilium pro auertenda à populo Christiano pestilentia \& pro aliis instantibus eiusdem necessitatibus (Rome, Bladius: 1576).
} 
supplements. By the same token, because the Milanese list was intended for local use, it could be more complete as given.

While the inclusion and exclusion of intercessors varied from one civic center to another, the appearance of names was invariably governed by a hierarchical organisation based on the historical vitae of the chosen saints. In the Roman order, the invocations begin with the Father, Son, and Holy Spirit, followed by a three-fold petition to Mary. Then come the Archangels Michael, Gabriel, and Raphael, the prophets and church patriarchs, apostles and disciples, martyrs, popes and bishops and Church doctors, other male priests and saints, and finally, female saints. The Milanese list follows roughly the same order, but with female saints coming after male martyrs and before male bishops. In the categories of martyrs and bishops, Milanese names come at the top of the list, before the more universal saints, giving local figures the pride of place. In an abstract way, this hierarchical procession of celestial names in the litany was in symmetry with the organisation of participants in the procession and legitimised both the segregation of the penitents and the prime position of earthly potentes, be it the Doge, the Bishop, or the Pope. As above, so below.

In addition to the litany and the other prescribed liturgical items, the plague procession called for other unspecified musical performances during moments of repose. Paul v's Rituale romanum instructs that if the route of an extraordinary procession were to pass by a church, the participants should interrupt their Litany or the Psalm and enter, with the clergy singing antiphons or prayers to the patron saint of that place. ${ }^{19}$ The instruction in Borromeo's pamphlet to perform a prayer 'de Sancto, in cuius Ecclesia supplicationes fiunt' points precisely to those performance possibilities. If a prayer of such specificity is not readily at hand, a 1537 manual provides examples that would be suitable for different classes of patrons, such as antiphons for Apostolic patrons, for one and multiple martyrs, for pontiffs, or for virgin martyrs. ${ }^{20}$ While spoken prayers would have been serviceable for making these stations, there is evidence from across Renaissance Europe that more complex polyphonic music (outside the musical abilities of the average lay participant) was sometimes performed by ecclesiastical choirs or singers hired specifically for the occasion. Notably, in cases where we have good evidence concerning specific

19 Catholic Church, Rituale romanum (Paris, Societas typographica: 1623) 391.

20 Castello Alberto da, Liber sacerdotalis: nuperrime ex libris Sancte Romane ecclesie [et] quarundam aliar [um] ecclesiar [um] [et] ex antiquis codicibus apostolice bibliothece (Venice, Rabanis: 1537) 271r-272v. 
pieces performed, the works in question sometimes quote the litany formula. ${ }^{21}$ As Kendrick writes of such polyphony that incorporates litanies, 'Given the universal presence of the litany tone in the sonic memory of any early modern Catholic, these pieces allow for - one might almost say 'script in', as in film the participation of literally anyone present, no matter how musically illiterate otherwise, into the polyphonic performance.'. ${ }^{22}$ The recognition of the litany in these pieces invites the lay participants to tune in, so to speak, even during the static moments of the procession when they are silent. In these musical accretions at shrines and stations, we can discern yet another facet of the interrelationship between ritual elements in a procession. In this instance, part of the liturgical-musical program of a procession is determined by its route and the devotional architecture of the city, which is related, in turn, to the historical affinity between a community and its holy protectors.

As a phenomenon, plague-tide processions brought together the public and acknowledged that the plague, aside from being a personal physical and spiritual problem, was also one that befell the entire community and that required communal action. A variety of ritual elements - from the relics used to the music sung - mutually reinforced each other to facilitate social cohesion. Fostering such a sense of social awareness and solidarity was undoubtedly commendable, but the wisdom of the actual processions was frequently disputed. It was recognised, right from the time of the Black Death, that plague was highly contagious. A Pisan chronicler observed that 'when [the crew of two Genoese galleys] reached the fish market someone began to talk with them and immediately he fell ill and died; others who talked with them also became ill as well as any who were touched by those who had died [...] and

21 Josquin's Pater noster / Ave Maria or the motets of TrevBC 29, for example. See Kellman H., "Josquin and the Courts of the Netherlands and France: The Evidence of the Sources", in Lowinsky E. - Blackburn B.J. (eds.), Josquin Des Prez: Proceedings of the International Josquin Festival-Conference Held at the Juilliard School at Lincoln Center in New York City, 21-25 June 1971 (London - New York: 1976) 181-216; Bryant D. - Pozzobon M., Musica devozione città: la Scuola di Santa Maria dei Battuti (e un suo manoscritto musicale) nella Treviso del Rinascimento, Memorie/Monografie 4 (Treviso: 1995); O’Regan N., "Processions and Their Music in Post-Tridentine Rome", Recercare 4 (1992) 45-80.

22 Kendrick R., "Honore a Dio, e allegrezza alli santi, e consolazione alli putti': The Musical Projection of Litanies in Sixteenth-Century Italy", in Ditchfield S. (ed.), Plasmare il suono: Il culto dei santi e la musica (secc. XVI-XVIII), Sanctorum 6 (Rome: 2009) 46. 
thus was sparked the great corruption that killed everyone.. ${ }^{23}$ Given such fears over contagion, governments sometimes forbade general processions, either directly or indirectly through the imposition of quarantines and curfews. ${ }^{24}$ During the 1576 outbreak, health officials in both Venice and Milan objected to the processions that eventually went ahead anyway. ${ }^{25}$

The anxiety of magistrates over the safety of processions is equally evident in Giovanni Filippo Ingrassia's 1576 Informatione del pestifero et contagioso morbo. In this plague treatise, the physician cautions his readers against congregating in crowds, since 'it is among such large groups that the contagion has prevailed up until now and continues to prevail, given that their bodies are filthy and their clothes dirty'. ${ }^{26}$ For the same reason, Ingrassia advises that town squares and churches should be avoided. In his treatment of the procession elsewhere in the treatise, however, he is more ambivalent. Ingrassia recognises that, while the procession is a 'divine remedy' that can be 'supported by many reasons and examples', it can nevertheless pose a difficulty for disease containment. ${ }^{27}$ Despite his misgivings, the pious doctor ultimately supports the ritual and tries to downplay the threat of contagion with an appeal to faith:

Those who are not in favour [of processions] think that it will avoid a great unruly multitude of people in the midst of this highly dangerous contagion. But I am of the opinion that we should not abandon the idea for that reason [...]. Who could think, as a faithful Christian, that if the people go to worship the Holy Sacrament with devotion, weeping and praying for grace, that they would succumb to plague? ${ }^{28}$

23 Sardo Ranieri, Cronaca di Pisa, Banti O. (ed.), Fonti per la storia dell'Italia moderna e contemporanea (Roma: 1963) 96; cited in Cohn S.K. Jr., The Black Death Transformed:Disease and Culture in Early Renaissance Europe (Oxford: 2002) 112.

24 In the early sixteenth century, for example, Giovanni Cambi complained bitterly of the Florentine ban on processions during the plague: 'This seemed a great abomination, for in tempestuous times one customarily turns to God, but we have made ourselves suspicious of the feasts of God and of the saints'; Cambi Giovanni, Istorie di Giovanni Cambi, cittadino fiorentino, ed. Ildefonso di San Luigi, 4 vols., Delizie degli eruditi toscani $20-23$ (Florence, Cambiagi: 1785) 22:237.

25 Fenlon I., The Ceremonial City: History, Memory and Myth in Renaissance Venice (New Haven: 2007) 225; Giussano, Life of St. Charles Borromeo 391.

26 Ingrassia Giovanni Filippo, Informatione del pestifero et contagioso morbo, Ingaliso L. (ed.), Filosofia e scienza nell'età moderna 19 (Milan: 2005) 420.

27 Ingrassia, Informatione del pestifero 349.

28 Ibid., 353 . 
If there is little reassurance in Ingrassia's rhetorical question, his attempt to downplay the dangers of processions is less helpful still; the doctor points out that very few people actually catch the plague on procession days (perhaps he had not read Gregory's legend very closely) - and those who do are probably not worthy of God's grace in any case $!^{29}$

Ingrassia's equivocations betray the difficulty of reconciling religious zeal with public safety, and the belief in processions as a miracle cure with the fear of the ritual as a hotbed of contagion. What could the devout do, then, if they wished to participate in processions, but for reasons of illness and quarantine, or for fear of contagion, could not? A piece of advice from Borromeo is pertinent here; to those who could not attend mass in the midst of plague, he said, 'Go to church in spirit', making viable the substitution of physical presence with an imaginative attendance. ${ }^{30}$ While the harrowing plague-tide factors motivating Borromeo's solution in this instance may be extraordinary, such virtual devotional acts themselves were not. Popular meditation guides of the period, for example, encouraged their readers, with the help of visual aids, to imagine themselves with Christ as he suffered his Passion. ${ }^{31}$ The sacro monte in Varallo just outside Milan - financially supported and frequented by Borromeo, who called the complex a 'New Jerusalem' - sent visitors to the Holy Land with chapels arranged to tell a Christological narrative, made even more vivid by thousands of statues and painted figures. ${ }^{32} \mathrm{In}$ an even more direct parallel to our quarantined Milanese, cloistered nuns were encouraged to go on pilgrimages imaginatively, since travel outside their convents was impossible. For such an exercise, they relied on pilgrims' diaries and narrative travelogues, maps, images of landmarks, and souvenir relics to imagine the visual and affective experiences of a journey, and they even made use of 'scripts' in devotional literature (say certain prayers while walking a certain distance, for instance) to verbally and somatically act out a pilgrimage. ${ }^{33}$

29 Ibid., 350.

$30 \quad$ Cited in Barker S., "The Gendered Imagination and Plague Art in Early Modern Italy" (Paper, Renaissance Society of America Annual Meeting, Venice, 10 April 2010).

31 Freedberg D., The Power of Images: Studies in the History and Theory of Response (Chicago: 1989) 161-191.

32 See for example, Freedberg, The Power of Images 192-245; Leatherbarrow D., "The Image and Its Setting: A Study of the Sacro Monte at Varallo", RES: Anthropology and Aesthetics $14(1987) 107-122$.

33 See for example, Rudy K., Virtual Pilgrimages in the Convent: Imagining Jerusalem in the Late Middle Ages (Turnhout: 2011); Rudy K., "A Guide to Mental Pilgrimage: Paris, Bibliothèque de L'Arsenal Ms. 212", Zeitschrift für Kunstgeschichte 63, 4 (2000) 494-515; Baernstein P.R., A Convent Tale: A Century of Sisterhood in Spanish Milan (Abingdon: 2013); 
Activating a similar kind of devotional imagination, one could, by extension, stay at home during the Borromean plague and attend a procession 'in spirit'. On this point, we can draw important lessons from Borromeo's devotional provisions outlined in his Constitutiones et decreta de cura pestilentiae, a handbook for parish clergy and health workers. One of the chapters of the Constitutiones is devoted to spiritual activities in public administrative spaces and closed-up homes. In it, the clergy are told to prepare each household for the devotional activities devised for the extraordinary circumstances by teaching them a variety of prayers, litanies, and Psalms ahead of the quarantine. During the quarantine, bells across the parish were to be rung seven times a day, approximately every two hours, to call the households to prayer. Once begun, the bell would be rung again every quarter hour, until the fourth bell signals an end to the hour of prayer. While the bell rings,

litanies or supplications will be chanted or recited at the direction of the Bishop. This will be performed in such a way that one group sings from the windows or the doors of their homes, and then another group sings and responds in turn. ${ }^{34}$

To ensure that these prayers are carried out properly, the decree continues, a member of the clergy or someone trained in these prayers (possibly the head of the household) should also come to a window or door at the appointed times to direct the prayers and stir up enthusiasm for this devotion.

To further facilitate these devotional activities, Borromeo instructed the parish clergy to be supplied with books 'that contain certain prayers, litanies, and oration, which will be made freely available, in order that he may go and distribute them to his own or other parishes. ${ }^{35}$ What are these books? From Giovanni Pietro Giussano's hagiography of Borromeo, we learn that this was liturgical literature that was especially printed for the occasion: 'when [the bell] sounded, all the inhabitants attended at their windows, a priest or other person appointed began the prayers, and all the people on their knees made the responses, each having the book of prayers which the Cardinal had printed for the purpose. ${ }^{36}$ It is possible that the prayer book described here refers to

Ehrenschwendtner M.L., "Virtual Pilgrimages? Enclosure and the Practice of Piety at St Katherine's Convent, Augsburg", Journal of Ecclesiastical History 6o, 1 (2009) 45-73.

Borromeo Carlo, Constitutiones et decreta de cura pestilentiae; ex concilio provinciali quinto mediolanensi extracta (Venice, Franciscum de Franciscis Senensem: 1595) 55-56. I would like to thank David Jacobson for his help with this translation.

35 Borromeo, Constitutiones et decreta 56.

36 Giussano, Life of St. Charles Borromeo 419. 
the Antiphonae, psalmi, preces, et orationes. If that is the case, then we have even more direct evidence that Borromeo's devotional program was meant to mirror the liturgical framework of the processions on the street.

Borromeo's directive to sing at doors and windows was evidently put into practice and impressed a number of chroniclers. In his Relatione verissima, Paolo Bisciola reports:

[W]hen the plague began to grow, this practice [of singing the litanies in public] was interrupted, so as not to allow the congregations to provide it more fuel. The orations did not stop, however, because each person stood in his house at the window or door and made them from there [...] Just think, in walking around Milan, one heard nothing but song, veneration of God, and supplication to the saints, such that one almost wished for these tribulations to last longer. ${ }^{37}$

Giussano likewise remarks on the harmonious piety of Milan, even going so far as to describe the plague-stricken city as heaven on earth on account of the pious singing:

It was a sight to see, when all the inhabitants of this populous city, numbering little short of three hundred thousand souls, united to praise God at one and the same time, sending up together an harmonious voice of supplication for deliverance from their distress. Milan might at this time have been not unfitly compared to a cloister of religious of both sexes serving God in the inclosure [sic] of their cells, an image of the heavenly Jerusalem filled with the praises of the angelic hosts. ${ }^{38}$

We can imagine the astonishment of these chroniclers, hearing the disembodied voices emerging from isolated homes all around, aggregating and blanketing an entire parish in song.

Borromeo's transference of the public procession from the street and into the home depended on - and was regulated by - sound. The ritual began with the sound of church bells, which not only signalled the times of the prayers, but also, as Sarah Hamilton and Andrew Spicer describe, intruded into domestic spaces from without, 'denoting the lordship and dominion of a particular

37 Bisciola, Relatione verissima $3 \mathrm{v}-4 \mathrm{r}$.

38 Giussano, Life of St. Charles Borromeo 419-420. 
house [of worship] over its territory.'39 The bells thus extended the sacred spaces of the parish into the homes. There, led by stationed liturgical leaders, the Milanese sang together. The litany, which so effectively encouraged participation and stitched together the processional body, became even more useful in suturing together members of segregated households; its musical simplicity and short-range call-and-response structure were essential when isolated neighbours could not even see each other. With their voices comingling, the penitents breached the walls between each other's houses, and between their homes and the streets, eroding the conceptual boundaries between public and private worship. Giussano's comparison of citizens praying in their enclosed homes to monks and nuns serving God in their cloister cells aptly describes this liminal state that is both communal and private, shared and isolated. The comparison also helps situate Borromeo's virtual processions within a larger context of spiritual exercises, such as the imaginative pilgrimages described earlier - with one important difference. While maps, itineraries, and other visual aids were helpful for those personal and solitary devotional acts, here, music is indispensable in coordinating the corporate, interactive ritual, allowing penitents to project themselves back onto the streets and re-join each other virtually in their beleaguered city.

\section{$5 \quad$ Conclusions: Processional Books and Dirty Books}

By way of concluding, I wish to speculate on other indications that premodern Europeans may have brought plague-related devotional activities into the home, and on other materials that may have helped penitents go on processions 'in spirit'. In the absence of the kind of pestilential prayer books that Borromeo issued, many Christians would still have had a cheap, printed book of hours on hand. ${ }^{40}$ As Virginia Reinburg describes them, these prayer

39 Hamilton S. and Spicer A., "Defining the Holy: The Delineation of Sacred Space", in Spicer A. - Hamilton S. (eds.), Defining the Holy: Sacred Space in Medieval and Early Modern Europe (Aldershot: 2005) 7 .

40 L.M.J Delaissé called the book of hours 'the first medieval best-seller', which is particularly true of France, England and the Low countries, to a lesser extent in Germany and Italy. Some were deluxe illuminated editions fit for royalty, but down-market prints were also widely and more cheaply available. See Wieck R.S. (ed.), Time Sanctified: The Book of Hours in Medieval Art and Life (New York: 2001) 28-31; Dondi C., "Pathways to Survival of Books of Hours Printed in Italy in the Fifteenth Century", in Myers R. - Harris M. - Mandelbrote G. (eds.), Books on the Move: Tracking Copies through Collections and the Book Trade, (London: 2007) 113-132; Hindman S. and Marrow J. (eds.), Books of Hours 
books 'provided a bridge between the liturgy and the home,' and the devotional practices prescribed and described therein 'were at the same time both individual and collective, public and private. ${ }^{41}$ Books of hours allowed the devout to carry with them the rituals that they participated in publically and to re-create them wherever they happened to be. Books of hours facilitated that goal in a variety of ways. They may have included pictures that further invoked the stock of images that the votary already knew from other devotional places, imaginatively transporting her into the scene depicted or other ritual spaces. ${ }^{42}$ The text of the prayers themselves may have encouraged performance, both musical and physical. Some prayers, such as the common rhyming sequence to St. Sebastian 'O Sancte Sebastiane, semper vespere et mane', were possibly designed to be sung. ${ }^{43}$ Others committed the votary to devotional movements. A prayer that tells Mary, 'At your holy feet ... with humble heart and prostrate body, I pray', for example, adopts a virtual posture of humility for the devotee. Another that describes penitents who come to St Martha 'hands joined, knees bent, heads uncovered' portrays a procession. ${ }^{44}$ Like a script, such prayers guide the votary through the enactment, either actual or imaginative, of devotional rituals and gestures.

Is it possible, then, that books of hours could have facilitated the 'domestication' of the anti-pestilential procession? Art historian Kathryn Rudy's innovative work on the material signs of use in books of hours is revealing. ${ }^{45}$ Using a densitometer, a device that measures the darkness of a surface, she compared the dirtiness of pages of various books of hours to determine which were the most handled - and therefore most used - by the user (or even users across generations) ${ }^{46}$ The results for one Dutch book are particularly interesting for our purposes. In MS $74 \mathrm{G}_{35}$, held at the Koninklijke Bibliotheek in The Hague, the Hours of the Virgin are, across the board, the dirtiest, likely on account of the quotidian use of this office. In the later sections of the book, the

Reconsidered, Studies in Medieval and Early Renaissance Art History (Turnhout: 2013) $6-7$.

Reinburg V., French Books of Hours: Making an Archive of Prayer, C. 1400-16oo (Cambridge: 2012) 6 .

42 Ibid., 123-125.

43 Ibid., 146.

44 Ibid., 165 .

45 Rudy K., "Dirty Books: Quantifying Patterns of Use in Medieval Manuscripts Using a Densitometer", Journal of Historians of Netherlandish Art 2, 1-2 (2010), 1-26: http://www .jhna.org/index.php/past-issues/volume-2-issue-1-2/129-dirty-books.

46 Rudy avoids dark patches that result from damage and calibrates her reading against the natural darkness of the vellum. 
densitometer spiked again at the Penitential Psalms and at the Litany of the Saints that follows them. The dirtiest pages in the entire book, however, are in the suffrage section and contain an antiphon to St. Sebastian:

Distinguished martyr Sebastian, master and propagator of the holiest teachings, behold your name written in the book of celestial lives. Therefore, intercede for us all. By the honouring of your memory to our Lord Jesus Christ, may he deign always to liberate us from plague and from epidemic death. Pray for us, blessed Sebastian, so we are made worthy of the promises of Christ.

The Penitential Psalms, the Litany of the Saints, and a prayer against pestilence - the user(s) of this book of hours handled those pages over and over again, clear evidence that plague weighed heavily on their minds. It is impossible to know for certain, of course, from the signs of wear in the book alone how they performed these prayers (was this a solitary performance, or did the whole family sing the Litany, creating a different kind of 'processional' community?) or whether they even performed them with the procession in mind. Nevertheless, the availability of the liturgical elements of the anti-pestilential procession at their (dirty) fingertips - and in a book, no less, whose generic expectations included singing, enacting pious gestures, and making public rituals private - makes such a domestication of the ritual an attractive possibility.

Then, as now, the management of disease was not a straightforward project. In times of plague, civic and religious leaders had to carefully balance the demands of spiritual and biological health, both communal and individual. When faced with the obstacles posed by the threat of contagion, pre-modern Christians found new ways to carry out their spiritual duties as a community. Within this picture, singing served as an essential tool for maintaining a continuity of devotional practice in the challenging conditions of plague. Whether performed publically or behind doors and windows, music brought the prayerful thoughts and spirits of the penitents together to fight against the communal scourge. The devotional activities during the outbreak in Milan can teach us many lessons on the texture of ritual practices in this period. Those activities can reveal to us, in turn, the extraordinary resilience and adaptability of the devout in the face of crisis. As Randolph Starn writes, '[the] chronic presence of disease suggests that we should not think of medieval and early modern societies as caught in the grip of plague-year panics or as waiting passively to be delivered by modern medicine. The newer accounts [of plague history] speak of "experienced populations," of well-organized institutional responses, of 
resourceful strategies for survival' ${ }^{47}$ Our history of Milanese devotion in times of pestilence is precisely such a narrative of organisation and resourcefulness.

\section{Selective Bibliography}

Bell C., Ritual: Perspectives and Dimensions (Oxford: 1997).

Besta Giacomo Filippo, Vera narratione del successo della peste, che afflisse l'inclita città di Milano l'anno 1576 et di tutte le provisioni fatte a salute di essa città (Milan, Paolo Gottardo \& Pacifico Pontij fratelli: 1578).

Bisciola Paolo, Relatione verissima del progresso della peste di Milano. Qual principiò nel mese d'Agosto 1576, e segui sino al mese di Maggio 1577 (Bologna, Carlo Malisardi and Sebastiano Balestra: 1630).

Borromeo Carlo, Antiphonae, psalmi, preces, et orationes, ad usum supplicationum tempore pestis (Milan, Pacificum Pontium: 1576).

Borromeo Carlo, Constitutiones et decreta de cura pestilentiae; ex concilio provinciali quinto mediolanensi extracta (Venice, Franciscum de Franciscis Senensem: 1595).

Carmichael A., "Contagion Theory and Contagion Practice in Fifteenth-Century Milan", Renaissance Quarterly 44, 2 (1991) 213-256.

Catholic Church, Litaniae et preces iussu S.D.N. Gregorij Papae XIII in omnibus ecclesijs dicendae ad implorandum diuinum auxilium pro auertenda à populo Christiano pestilentia \& pro aliis instantibus eiusdem necessitatibus (Rome, Bladius: 1576).

Cohn S.K. Jr., Cultures of Plague:Medical Thought at the End of the Renaissance (Oxford: 2011).

Dallaj A., "Le Processioni a Milano Nella Controriforma", Studi Storici 23, 1 (1982) 167-83. de Boer W., The Conquest of the Soul: Confession, Discipline, and Public Order in CounterReformation Milan (Leiden - Boston: 2001).

Filippi Daniele V., "Carlo Borromeo e la musica, 'a lui naturalmente grata", in Addamiano A. - Luisi F. (eds.), Atti del Congresso Internazionale di Musica Sacra (Roma, 26 maggi - 1 giugno 2011), 3 vols. (Vatican: 2013) 2:665-676.

Flanigan C., "The Moving Subject: Medieval Liturgical Processions in Semiotic and Cultural Perspective", in Ashley K. - Hüsken W. (eds.), Moving Subjects: Processional Performance in the Middle Ages and the Renaissance, Ludus: Medieval and Early Renaissance Theatre and Drama 5 (Amsterdam - Atlanta: 2001) 35-51.

47 Starn R., Foreword to Histories of a Plague Year: The Social and the Imaginary in Baroque Florence, ed. G. Calvi, trans. D. Biocca - B.T. Ragin (Berkeley: 1989). 
Getz C., "Canonising San Carlo: Sermonising, the Sounding Word, and Image Construction in the Music for Carlo Borromeo", Early Music History 34 (2015), 133-189.

Getz C., Music in the Collective Experience in Sixteenth-Century Milan (Burlington: 2005).

Giussano Giovanni Pietro, The Life of St. Charles Borromeo, Cardinal Archbishop of Milan: From the Italian of John Peter Giussano; With Preface by Henry Edward Cardinal Manning [Vita Di S. Carlo Borromeo (Rome, 1610)] (London - New York: 1884).

Kendrick R., "'Honore a Dio, e allegrezza alli santi, e consolazione alli putti': The Musical Projection of Litanies in Sixteenth-Century Italy", in Ditchfield S. (ed.), Plasmare il suono: Il culto dei santi e la musica (secc. XVI-XVIII), Sanctorum 6 (Rome: 2009) $15-46$.

O'Regan N., "Processions and Their Music in Post-Tridentine Rome", Recercare 4 (1992) $45^{-80 .}$

Reinburg V., French Books of Hours: Making an Archive of Prayer, C. 1400-160o (Cambridge: 2012).

Rudy K., "Dirty Books: Quantifying Patterns of Use in Medieval Manuscripts Using a Densitometer" Journal of Historians of Netherlandish Art 2, 1-2 (2010), http://www .jhna.org/index.php/past-issues/volume-2-issue-1-2/129-dirty-books.

Trexler R., Renaissance Florence: The Public Life of a Complex Society (New York: 1980). 